\title{
OLD WORDS AND THE NEW WORLD: LIBERAL EDUCATION AND THE FRANCISCANS IN NEW SPAIN, I536-I6oI* The Whitfield Prize Winner
}

\author{
By Aysha Pollnitz
}

\begin{abstract}
The Colegio de Santa Cruz de Tlatelolco, established in I536, liberally educated the sons of Nahua (Aztec) leaders in New Spain. Its Franciscan pedagogues, including Bernardino de Sahagún (c. I499-I590), Andrés de Olmos (I49I-I57I) and Juan Bautista (c. I555-1606/I3), worked with indigenous students and alumni to collect, edit and circulate Nahuatl huehuetlahtolli, or 'speech of the ancients'. This paper examines the largest collection of these orations printed in premodern Mexico, the Huehuetlahtolli [I60I] edited by Juan Bautista and indigenous intellectuals from the college. It argues that the Tlatelolcans adapted Nahuatl 'old words' for the New World of colonial society. They ornamented the speeches with rhetorical techniques derived from Santa Cruz's Erasmian curriculum. They interpolated biblical sentences, particularly from Proverbs and Sirach, to enhance the evangelising potential of the discourses. Finally, they drew on Erasmus's theory of speech, as expressed in his pedagogical and spiritual writings, to explicate Nahuatl los difrasismos concerning eloquence and good counsel. Contextualising the Huehuetlahtolli [160I] in Santa Cruz's Erasmian schoolroom reveals the contours of its argument for vernacular evangelisation, the liberal education of indigenous youth and for the elegance of the Nahuatl tongue.
\end{abstract}

On 6 January 1536 , the feast of the epiphany was marked by a solemn procession in Mexico City. It began with a sermon at the convent of San Francisco near Tenochtitlan, the fallen Aztec capital. ${ }^{\mathrm{I}}$ Then friars processed behind the viceroy, Antonio de Mendoza (c. I490-I552), the former president of the second Audiencia of Mexico and the second bishop of Santo Domingo, Sebastián Ramírez de Fuenleal (c. I490-I547)

* The author thanks Rice University, the John Carter Brown Library and Grinnell College for their generous support. She is grateful to the Transactions's editor and anonymous reviewers for their perspicacious counsel. She thanks members of the Sixteenth-Century Historical Society, the Harvard Early Modern Workshop, fellows of the John Carter Brown Library, the Rice Medieval and Early Modern Workshop, Andrew Laird, David Armitage and Susan Kellogg for their sage advice on earlier versions of this article.

${ }^{\text {I }}$ Gerónimo de Mendieta, Historia eclesiástica Indiana, ed. Joaquín García Icazbalceta (Mexico, I870) IV:I5, 4I4-18; Pedro de Gante to Charles V, 3I Oct. I532 in Cartas de Indias (Madrid, I877), 52. 
and the Franciscan bishop of Mexico, Juan de Zumárraga (I468-I548). They walked two miles north to the Convent of Santiago, Tlatelolco where they inaugurated the Colegio Imperial de Santa Cruz. There, indigenous students would study Latin grammar, rhetoric, philosophy, logic and (some hoped) theology. Prior to the conquest, the site at Tlatelolco had been a calmecac, a traditional school where Nahua elites had learned to speak well, to govern and to hear suits. Now, liberal education at the college would lay the path towards an epiphany for New World gentiles. ${ }^{2}$

Santa Cruz was immediately, if not durably, an academic success. Its alumni became native governors and allies in the spiritual conquest of New Spain. Erudite trilingual students, whom the friars called gramaticos or ladinos, also helped the Franciscans to create texts that described precontact Nahua language and culture. Pride of place in their endeavours went to the collection of huehuetlahtolli, 'speech of the ancients', or palabras antiguas, historia antigua or dichos de viejos in Spanish. ${ }^{3}$ These speeches were Nahuatl orations including: prayers to the gods, counsel to officeholders and moral exhortations to children. The 'ancients' spoke in highly figurative language, larded with los difrasismos, couplets of juxtaposed synonyms or syntactically linked words that formed metaphors. Not only did los difrasismos elevate the discourse stylistically but it enriched it conceptually, one of the reasons that huehuetlahtolli are central to scholarly attempts to explicate Nahuatl thought. ${ }^{4}$ The largest collection of 'speech of the ancients' is contained in Book VI of the Florentine Codex. ${ }^{5}$ On the Spanish title-page, the Tlatelolcan missionary and teacher, fray Bernardino de Sahagún (I499-I590), described the speeches as 'the Rhetoric, and moral philosophy, and theology of Mexican people'

${ }^{2}$ Mendieta, Historia, IV:I5, 4I4-I8; Informe de la provincia de Santo Evangelio, al visitador Lic. Juan de Ovando, in Códice Franciscano, siglo XVI, ed. Joaquín García Icazbalceta (Mexico, I94I), 62-5; Juan Bautista Pomar, Relación de Tezcoco (siglo XVI), ed. Joaquín García Icazbalceta (Mexico, I975), 28.

3 Andrés de Olmos, Arte para de la lengua Mexicana [1547], ed. Ascensión Hernández de León-Portilla and Miguel León-Portilla (Mexico, 2002), I77; Alonso Molina, Aqui comiença vn vocabulario enla lengua Castellana y Mexicana (Mexico: Juan Pablos, I555), fo. I5Ir, and (Mexico: Antonio de Spinosa, I57I), fo. I57r. See The Art of Nahuatl Speech: The Bancroft Dialogues, ed. Frances Karttunen and James Lockhart (Los Angeles, I997), 8 n. I I.

4 Mercedes Montes de Oca Vega, Los difrasismos en el Náhuatl de los siglos XVI y XVII (Mexico, 20I3), I3, 2I-8, 38-4I; Thelma D. Sullivan, 'The Rhetorical Orations, or Huehuetlatolli, Collected by Sahagún', in Sixteenth-Century Mexico: The Work of Sahagún, ed. Munro S. Edmonson (Albuquerque, I974), 79-Io9; Ángel María Garibay Kintana, Historia de la literature Náhuatl (2 vols., Mexico, I953), I, 65-7; but see M. José García Quintana, 'Los huehuetlahtolli en el Códice Florentino', in Fray Bernardino de Sahagún y su tiempo, ed. Jesús Paniagua Pérez and María Isabel Viforcos Marinas (Leon, 2000), 553-7I.

5 Bernardino de Sahagún, Florentine Codex: General History of the Things of New Spain, ed. Charles E. Dibble and Arthur J. O. Anderson (I3 vols., Santa Fe, I950-82), I, 54. In subsequent footnotes, Sahagún is credited with authorship of Spanish prologues and glosses but treated as an editor of Nahuatl huehuetlahtolli. 
and as pertaining to both 'the foundations of their language' and 'the moral virtues'. ${ }^{6}$ According to the Codex, huehuetlahtolli were traditional instruments of native education, a topic that held considerable interest for the denizens of the Colegio de Santa Cruz.

Rather than considering the Florentine Codex, this article focuses on a less frequently discussed collection of Huehuetlahtolli [I60I] printed in Mexico by fray Juan Bautista (I555-c. I6I3), the guardian of the convent at Tlatelolco. This octavo, printed in a plain style on ninety-five leaves of inexpensive paper, contains twenty-nine Nahuatl speeches and eight Spanish pláticas. They were predominantly speeches to youths, with a few exhortations to rulers. Bautista claimed to have received a number of Nahuatl and Spanish orations from fray Andrés de Olmos (I480?I568), a missionary who had arrived in New Spain with Zumárraga in $1528 .^{7}$ The published text constitutes the second largest collection of Nahuatl oratory to survive and the only such anthology printed in Mexico. ${ }^{8}$ While it was not reprinted, Spanish versions of the orations were circulated widely. The Huehuetlahtolli shares certain features with the Florentine Codex: topics of discourse, the use of certain metaphors, and an emphasis on humble conduct, obedience to higher powers and self-discipline. As such, studies of the huehuetlahtolli have mined them for evidence of pre-contact Nahuatl language, culture and cosmo-vision. ${ }^{9}$

6 'de la Rethorica y philosophia moral, y theologia: de la gente mexicana... tocantes a los primores de su lengua y.... a las virtudes morales': Sahagún, Florentine Codex, VII, unpaginated front matter.

7 Huehuetlahtolli, ed. Juan Bautista (Tlatelolco: [Melchior Ocharte? Cornelio Adrián César? Diego López Dávalos?], [I6or]), sigs. L5r, N3v-N4r. The two surviving copies of the text (John Carter Brown Library, Providence RI, B6or J9Ih and B6or J9Ih c.2) are missing their title-page and several leaves from the first quire. On possible reconstructions for the title-page, see Juan Pascoe, Cornelio Adrián César: impresor holandés en México, 1597-1633 (Santa Rosa, 2016), 262-7I. In subsequent footnotes, Bautista is credited with authorship of the Spanish prologue but treated as an editor of Nahuatl huehuetlahtolli.

8 The speeches in Sahagún's Florentine Codex and Primeros memoriales remained in manuscript. Following the royal prohibition of the General History in April I577, the friar's papers were confiscated. Some documents, possibly including the Primeros memoriales, were sent to Madrid. The illustrated Nahuatl and Spanish version of the General History, known as the Florentine Codex, was protected by Fray Rodrigo de Sequera, the Franciscan's general commissary in New Spain. Sequera took the Codex to Spain in 1580 and it arrived in Florence prior to I588: Lluís Nicolau d'Olwer, Fray Bernardino de Sahagún, I499-I590, trans. Mauricio J. Mixco (Salt Lake City, 1977), 72-7. Also in manuscript was the short collection of conversations and brief speeches from late sixteenth- or seventeenth-century Texcoco, associated with Horacio Carochi: The Bancroft Dialogues, ed. Karttunen and Lockhart, 2-10.

9 For example: Ángel María Garibay Kintana, 'Huehuetlatolli, documento A: nota introductoria', Tlalocan, I (I943), 31-80; Josefina García Quintana, 'El huehuetlatolli antigua palabra - como fuente para la historia sociocultural de los nahuas', Estudios de Cultura Náhuatl, I2 (1976), 61-7i; Sullivan, 'The Rhetorical Orations, or Huehuetlatolli', 79Iog; Miguel León-Portilla, The Aztec Image of Self and Society: An Introduction to Nahua Culture, ed. J. Jorge Klor de Alva (Salt Lake City, I992); Georges Baudot, Utopia and History in Mexico: 
Nevertheless, the Huehuetlahtolli contains more loan words and Christian doctrine than the Codex. Some recent scholarship has identified its colonial context and evangelising purpose. ${ }^{\mathrm{IO}}$

This paper develops this research in a novel direction by considering the significance of the Colegio de Santa Cruz and its humanist orientation on the generation of the Huehuetlahtolli. The collection of speeches was probably created for the instruction of Franciscan novices, who were learning to preach in Nahuatl, and indigenous students. School use would explain the inexpensive print and low rate of surviving copies. The first section examines the way that Santa Cruz missionaries used the orations in their classicised arguments about the civility of the indios. The second section investigates the humanistic source of this impulse by surveying the ideological leanings of the friars, the curriculum of Santa Cruz and the intellectual activities of its students and alumni. It identifies the persistent influence of Erasmus of Rotterdam (I466-I536), whose writings continued to be used at Tlatelolco despite their placement on papal and Spanish indices. As the final section shows, the friars and students who created the Huehuetlahtolli drew on the style and content of Erasmian 'good letters', or bonae litterae. Indeed, by contextualising the Nahuatl orations in Erasmus's pedagogical and spiritual writings, it is possible to see that the printed text was more than a collection of evangelising pláticas. The Huehuetlahtolli also made a powerful argument for the moral and political value of good speech, and for the spiritual benefits of Nahuatl-language evangelisation in the New World.

\section{The cultural encounter between old words in the New World}

Historians are increasingly cognisant that the encounter between European, Amerindian and African cultures shaped the institutions, laws and religion of New Spain. The texts created in this colonial environment were almost inevitably hybrid. ${ }^{\text {II }}$ Sophisticated studies by new philologists of Nahuatl translations of European texts and Nahuatl compositions in various European genres have opened a new vista on New Spain. Of particular importance for this study is the research that has shown

The First Chronicles of Mexican Civilisation (I520-I569), trans. Bernard R. Ortiz de Montellano and Thelma Ortiz de Montellano (Niwot, CO, I995).

${ }^{\text {Io }}$ Mónica Ruiz Bañuls, El huehuetlatolli como discurso sincrético en el proceso evangelisador novohispano del siglo XVI (Rome, 2009).

${ }^{\text {II }}$ Peter Burke, Cultural Hybridity (Cambridge, 2009), 22-3; Serge Gruzinski, The Mestizo Mind: The Intellectual Dynamics of Colonisation and Globalisation, trans. Deke Dusinberre (New York, 2002); Diana Magaloni Kerpel, Los colores del Nuevo Mundo: artistas, materiales y la creación del Códice Florentino (Mexico, 2014); Gauvin Alexander Bailey, Art of Colonial Latin America (2005). 
that Christianity was transformed by Nahuatl translation. ${ }^{12}$ Until very recently, however, scholars have tended to treat huehuetlahtolli as immune from European influence. These repositories of authentic 'linguistic information' were deemed to reveal the 'political and religious speech used in the most diverse situations of daily life in the Mexica culture' and shed light on 'the pre-Hispanic Indian mind and thought'. ${ }^{13}$ This study, however, asks whether and how the Huehuetlahtolli was inflected by its colonial context. It takes its point of departure from scholars' frequent descriptions of the Nahuatl speech of the ancients as analogous to Greek and Roman discourse, as it was revived by humanists in the sixteenth century. ${ }^{\mathrm{I}}$ It contends that these modern comparisons derive from the way that the huehuetlahtolli was framed by humanists associated with the Colegio de Santa Cruz.

This is not an attempt to suggest that Europeans invented the huehuetlahtolli. Both pictorial codices and Nahuatl morphology show that eloquence played an important role in pre-contact Mesoamerica. Images in pre-Columbian and early contact codices depict rulers, priests and parents with the attribute of speech scrolls. ${ }^{5}$ The Nahuatl terms for ruler (tlatoani, 'speaker') and ambassador (tlatocatitlantli, 'messenger of the speaker') derive from the verb (i)htoa ('to speak'). ${ }^{16}$ Nahua political, religious and familial culture evidently had recourse to a repository of past speech acts, which they described to the Franciscans as huehuetlahtolli. Nevertheless, the surviving pláticas were recorded in alphabetised form after the arrival of Europeans; Franciscans and Jesuits, including Andrés de Olmos, Bernardino de Sahagún, Juan Bautista and, later, Horacio Carochi (I586-1666), initiated the process. Liberally educated Tlatelolcans did not concoct the 'speech of the ancients, but they certainly inflected the form in which we have received it.

${ }^{12}$ See the research of Louise M. Burkhart, Mark Z. Christensen, Rebecca Horn, Frances Karttunen, James Lockhart, Stafford Poole, Barry D. Sell, Susan Schroeder, John Frederick Schwaller, David Tavárez, Camilla Townsend and Stephanie Wood, among others.

${ }^{13}$ Baudot, Utopia and History in Mexico, 223; and Sullivan, 'The Rhetorical Orations, or Huehuetlatolli', 79. See similarly León-Portilla, Aztec Image of Self and Society, 76; Garibay Kintana, 'Huehuetlatolli, documento A' 3I; García Quintana, 'El huehuetlatolli - antigua palabra', 6r-7I.

${ }^{\text {I4 }}$ Miguel León-Portilla, 'Huehuehtlahtolli: antigua palabra: la retórica Náhuatl', in $\mathrm{La}$ palabra florida: la tradición retórica indigena y nova hispana, ed. Helena Beristain and Gerardo Ramírez Vidal (Mexico, 2004), 23-40, at 39; Walter D. Mignolo, The Darker Side of the Renaissance: Literacy, Territoriality, and Colonisation (Ann Arbor, 1995), I43.

${ }^{15}$ Elisabeth Hill Boone, Stories in Red and Black: Pictorial Histories of the Aztecs and Mixtecs (Austin, 200o), 46, 57-8; Joyce Marcus, Mesoamerican Writing Systems: Propaganda, Myth, and History in Four Ancient Civilisations (Princeton, 1992), 48.

${ }^{16}$ Molina, Vocabulario (I57I), fos. 4V, I20r, I40v, I4Ir; Susan Kellogg, Law and the Transformation of Aztec Culture, I500-I700 (Norman, OK, I995), 221, 227; Thelma D. Sullivan, 'Nahuatl Proverbs, Conundrums, and Metaphors, Collected by Sahagún', Estudios de Cultura Náhuatl, 4 (I963), 93-178, at I50-I. 
Indeed, Franciscans teaching at Santa Cruz initiated descriptions of the huehuetlahtolli as analogous to classical rhetoric. In his Spanish prologue to Book VI of the Florentine Codex, Sahagún argued that, like the Greeks and Romans, and the modern Europeans who imitated them, the Nahua elected 'wise, virtuous and forceful Rhetoricians', who knew the huehuetlahtolli, to be 'high priests, lords, leaders, and captains, no matter how humble their estate. These [orators] ruled the states, led the armies, and presided in the temples. ${ }^{17}$ Missionaries claimed that pre-contact Nahua intellectuals had taught the huehuetlahtolli much as Renaissance humanists taught Virgil or Cicero. In a letter to the Jesuit José de Acosta (I540-I60o), fray Juan de Tovar (I543-I623) argued that Nahuatl orators and priests trained 'the principal youths, who were to be their successors', using 'continual repetition' of the speech of the ancients until they 'remain in their memories, without any discrepant words' ${ }^{18}$ In the prologue to the Huehuetlahtolli, fray Juan Bautista claimed that the study of ancient speech inculcated 'the precepts of natural law' and 'the virtues of Prudence, Justice, Fortitude, and Temperance' in Nahuatl youth, much as liberal education (allegedly) did in Europe. ${ }^{19}$ Book III of the Florentine Codex located this instruction in the calmecac, a place dedicated to 'the teaching of good letters (qualli tlahtolli)'. Qualli tlahtolli was a Nahuatl cognate of the Latin phrase, bonae litterae, that Erasmus had popularised to describe classical literature and scripture. ${ }^{20}$

Many educated Europeans saw the New World through a classical lens. ${ }^{21}$ When they compared classical Latin or Greek pedagogy to Mexican education, the missionaries were emphasising the wit and civility of the indios and the value of their mission. In the I530s, Ramírez de Fuenleal, the president of the second Audiencia, the body responsible for the administration of justice in Mexico, responded to Dominican attempts

\footnotetext{
${ }^{17}$ Sahagún, Florentine Codex, I, 65, and see i 65.

${ }^{18}$ 'sus oradores y poetas, había cada día ejercicio dello [en los colegios] de los mozos principales que habían de ser sucesores a estos, y con la continua repetición se les quedaba en la memoria, sin discrepar palabra': Juan de Tovar in Don Fray fuan de Zumárraga: Primer Obispo y Arzobispo de Mexico, ed. Joaquín García Icazbalceta, 2nd edn, ed. Rafael Aguayo Spencer and Antonio Castro Leal (4 vols., Mexico, I988), IV, 92-3. See also The Bancroft Dialogues, ed. Karttunen and Lockhart, I53.

I9 'todas las reglas y colores de la Rethorica' and 'podra dezir ... delos preceptos de la ley natural ... conciernen a las Virtudes de la Prudencia y Iusticia, y Fortaleza y Temperança': Huehuetlahtolli, ed. Bautista, fo. 92r-v.

${ }^{20}$ 'cenca vel nemachtiloia in qualli tlahtolli': Florentine Codex, ed. Sahagún, III, 67 (quotation), and VII, 93, 99, I05, II3. Cf. Erasmus, Collected Works of Erasmus, v: Letters 594-84I, ed. R. A. B. Mynors, trans. D. F. S. Thomson (Toronto, I979), 4II. Works in this series will be referred to hereafter as $C W E$.

${ }^{21}$ Anthony Pagden, The Fall of Natural Man: The American Indian and the Origins of Comparative Ethnology (Cambridge, 1982); David A. Lupher, Romans in a New World: Classical Models in Sixteenth-Century Spanish America (Ann Arbor, 2003); Sabine MacCormack, On the Wings of Time: Rome, the Incas, Spain, and Peru (Princeton, 2007).
} 
to disparage the indios' intellectual and moral capacities by turning to the Franciscans. $^{22} \mathrm{He}$ asked Andrés de Olmos and Bernardino de Sahagún to compile accounts of indigenous language and customs. Between I533 and I539, Olmos alternated between teaching Latin at Santa Cruz and meeting native principales in Tenochtitlan, Texcoco and Tlaxala to collect evidence of their political culture. A manuscript associated with Olmos described him seeking out 'the accounts of the elders, and of those who were priests and fathers in the time of their infidelity'. ${ }^{23}$ With the assistance of indigenous collaborators, Olmos transcribed and translated the speeches. He turned at least one plática into an appendix to his Arte de la lengua Mexicana [I547], a Nahuatl-Spanish grammar. ${ }^{24}$ It offered a version of indigenous culture that was well fashioned to please (or at least, to avoid frightening) fellow-missionaries.

In I6oi, Juan Bautista asserted that Olmos's Spanish translation of Nahuatl speeches were reliable. 'Nothing was added, and nothing of substance was taken away', he insisted. Olmos and his collaborators had exchanged 'sense for sense, not word for word', as Cicero and Erasmus had advised. ${ }^{25}$ Even a cursory comparison between the Spanish and Nahuatl versions of Olmos's speech reveals the translation to be a loose summary. As with other humanist translations, moreover, the object was not verisimilitude but an elegant argument. ${ }^{26}$ In this case, translations were intended to support the Franciscan mission.

${ }^{22}$ Sahagún, Florentine Codex, I, 53-6; José María Kobayashi, La educación como conquista: empresa franciscana en México (Mexico, I986), 23I-4. For an example of such criticism, see Jeronimo Lopez, letter to Charles V, I54I, in Colección de documentos para la historia de México (Mexico, I866), II, I48-50.

23 'por dicho de los señores y principales á quien se enseñaba la ley y criaban en los templos para que la deprendiesen': [Anon. poss. Olmos], 'Historia de los mexicanos por sus pinturas', in Teogonia e historia de los Mexicanos: tres opúsculos del siglo XVI, ed. Ángel María Garibay Kintana (Mexico, I965), 23.

${ }^{24}$ The speech survives in the following manuscripts of the Arte de la lengua Mexicana: Library of Congress, Washington, DC, Miscellaneous Manuscript Collection, box I83 (old number L.A. Misc. III-48-C, 4) Ac. 8 (I898); Bibliothèque nationale, Paris, Fonds espagnol, 259, Trichet du Fresne, Colbert (I665); Biblioteca Nacional de Madrid, MS ioo8ı/Reservado I65. See John F. Schwaller, 'Small Collections of Nahuatl Manuscripts in the United States', Estudios de cultura Náhuatl, 25 (I995), 377-4I6, at 4I4-15; Andrés de Olmos, Arte de la lengua Mexicana [I547], ed. Miguel Léon-Portilla (Madrid, I993), xxxviii; Judith M. Maxwell and Craig A. Hanson, Of the Manners of Speaking that the Old Ones Had: The Metaphors of Andrés de Olmos in the TULAL Manuscript (Salt Lake City, I992), IO-I I; Ruiz Bañuls, El huehuetlatolli, 239-43; 'Exhortación de un padre a su hijo. Texto recogido por Andrés de Olmos', ed. Josefina García Quintana, Estudios de cultura Náhuatl, I I (I974), I37-82.

25 'na sin añadir, ni q[ui]tar cosa q[ue] fuesse de substa[n]cia: saca[n]do sentido de sentido, y no palabra de palabra': Huehuetlahtolli, ed. Bautista, fo. 77r. Cf. Cicero, De optimo genere oratorum, IV.I3-V.I5, and Erasmus, Capita argumentorum contra morosos quosdam ac indoctos, in Opera omnia, ed. Jean le Clerc (Leiden: Van der Aa, I7o6), vI. sig. **v. See also ***r.

${ }^{26}$ See Paul Botley, Latin Translation in the Renaissance: The Theory and Practice of Leonardo Bruni, Giannozzo Manetti and Desiderius Erasmus (Cambridge, 2004); Erika Rummel, Erasmus' 
Olmos circulated selected Spanish orations to carefully chosen allies. In the wake of the I550 Valladolid debate with Juan Ginés de Sepúlveda (c. I490-I573), Olmos sent eight pláticas to Bartolomé de las Casas (c. I484I566), Dominican and bishop of Chiapas. Las Casas incorporated them in the second part of his Apologética historia (written $c$. $155^{6-9}$, printed I9o9). The Apologética vindicated the intellectual, moral and spiritual capacities of the indios against Sepúlveda's assertion that 'in prudence, wisdom, every virtue, and humanity' indigenous people were 'inferior to the Spaniards ... almost as monkeys are to men'.27 Las Casas retorted that the indios lived in a different but comparable manner to the gentiles. He used Olmos's huehuetlahtolli to show that the Mexica's discourse was sophisticated, even though they lacked an alphabetic script, and that their pedagogy rivalled the ancient Athenians and Romans. Indeed, Nahuatl speech could not be heard 'without great advantage to most of us who call ourselves Christian'. The Nahua, 'who have never read [Greek or Roman] philosophy', nevertheless adhered more 'closely to the rules of Aristotle' than supposedly civilised nations. ${ }^{28}$

Other early modern defenders of the indios also used Olmos's speeches in translation. In $\mathrm{I}_{585}$, for instance, the royal judge, Alonso de Zorita (I514-85), incorporated several in his Relación to Philip II. Zorita's renderings were similar to Las Casas's speeches but more compressed. Like Las Casas, Zorita used them to evidence the Mexica's pre-contact prudence in 'government and judicature, and in keeping the laws and doing justice and in raising their children'. The indios, he argued, were called 'barbarous' on account of their former idolatry and different customs, rather than their lack of elegant speech or civility. They owed much of their contemporary corruption to the rapaciousness of their conquerors. ${ }^{29}$

Annotations on the New Testament: From Philologist to Theologian (Toronto, I986); Cultural Translation in Early Modern Europe, ed. Peter Burke and R. Po-chia Hsia (Cambridge, 2007).

${ }^{27}$ 'qui prudentia, ingenio, virtute omni ac humanitate tam longe superantur ab Hispanis . . . denique quam simiae prope dixerim ab hominibus': Juan Ginés de Sepúlveda, Democrates alter, sive de justis belli causis apud Indos, ed. Marcelino Menéndez y Pelayo [I892] (Alicante, 2006), paragraph no. 304, access via URI: www.cervantesvirtual.com/nd/ ark:/5985I/bmccv4wo. Cf. Aristotle, Politics, I254bi5-I255a2. Regarding Indians and apes, see Pagden, Fall of Natural Man, i I7.

${ }^{28}$ sino muy grande ventaja muchos de los que nos llamamos christianos... Parece, pues, tanto ... y más de propincuo a las reglas del Philósopho, éstas, que nunca leyeron su philosophía, que otras muchas naciones en la crianza delos hijos haberse allegado': Bartolomé de las Casas, Apologética historia sumaria, III, in Obras completas, ed. Vidal Abril Castelló et al. (I4 vols., Madrid, I988-98), VIII, I393-4 (quotation), I398-I407 (speeches).

${ }^{29}$ 'aquellas gentes tenian en su gobierno y Judicatura y en guarder sus leies y hazer justiçia y en criar sus hijos': Alonso de Zorita, Relación de la Nueva España: Relación de algunas de las muchas cosas notables que hay en la Nueva España y de su conquista y pacificación y de la conversión de los naturales de ella, ed. Wiebke Ahrndt, Ethelia Ruiz Medrano and José Mariano Leyva (Mexico, I999), I52-5, 209-I8, 228-3I (quotation). 
Zorita had probably acquired the Spanish speeches from a draft of fray Gerónimo de Mendieta's (I525-I604) Historia eclesiástica indiana (c. I595). In addition to praising the Nahua's eloquence, Mendieta hazarded that their capacity to assimilate the liberal arts derived from their pre-contact pedagogy. ${ }^{30}$ Either Mendieta or, more probably, Bautista shared eight Spanish huehuetlahtolli with fray Juan de Torquemada (c. I557-I624), who printed expanded versions in his Monarquía Indiana (I6I5). Torquemada augmented the pláticas with scriptural references so that the ancient indios seemed to anticipate the words of the ancient Israelites. Their concern for 'good education and teaching of the youths' was Aristotelean and Platonic. The indios were clearly 'rational and political and living the lives of [civilised] men' and ripe for conversion. ${ }^{3{ }^{1}}$ In the late seventeenth century, Augustín de Vetancurt (I620-I700) took up the refrain, arguing that the speeches proved that the indios had 'put into practice honest customs in the education of their children' prior to European contact. ${ }^{32}$

The tradition of using Olmos's huehuetlahtolli as classical artefacts in the defence of the indios spread to accounts of the Americas printed in Europe. Fray Diego Valadés's Rhetorica Christiana (I579) described the glyphs that accompanied the 'speech of the ancients' as approaching letters for fixity and sophistication. In his oft-translated De natura Noui Orbis ( 1589 ), the Jesuit, Juan de Acosta, distinguished the 'barbarous' Chichimeca from the Mexica, who used 'the speeches that the orators and ancient rhetoricians made'. 33 Subsequently, Joannes de Laet's and Samuel Purchas's seventeenth-century compendiums of travel literature reiterated Acosta's claims for Dutch, French and English readers. ${ }^{34}$ These works did not include the speeches gathered by Olmos but they certainly referred to the huehuetlahtolli to propagate the mendicants' account of Mexican civility.

${ }^{30}$ Mendieta, Historia, II. 20-2, I I 2-20.

$3^{\mathrm{I}}$ 'la buena educación y doctrina de los niños ... para hacerlos racionales y políticos y que viviesen la vida de hombres que tenían': Juan de Torquemada, Monarquía indiana: de los veinte y un libros rituales y monarquía indiana, con el origen y guerras de los indios occidentales, de sus poblazones, descubrimiento, conquista, conversión y otras cosas maravillosas de la mesma tierra, ed. Miguel León-Portilla (7 vols., Mexico, I975-83), IV (I3:I6), 26I (quotation), 260-70 (speeches).

$3^{2}$ 'aprenderan a poner en ejecución las costumbres honestas en la crianza de sus hijos': Augustín de Vetancurt, Teatro mexicano: descripción breve de los sucessos exemplares, historicos, politicos, militares, y religiosos del nuevo mundo occidental de las Indias (Mexico: Maria de Benavides, [16978]), I, 85 .

33Diego Valadés, Rhetorica Christiana (Perugia: Petrus Jacobus Petrutius, I579), 93; 'parlamentos que hacían los oradores y retóricos antiguos': Juan de Acosta, Historia natural y moral de las Indias (Seville: Juan de Léon, I590), 408.

${ }^{34}$ Joannes de Laet, Nieuvve wereldt ofte beschrijvinghe van West-Indien (Leiden: Isaack Elzevier, I625), and quickly thereafter in Latin and French; Samuel Purchas, His Pilgrimage. Or Relations of the World and the Religions Obserued in All Ages and Places (William Stansby for Henrie Fetherstone, I625), and thereafter. 
There was, as Thelma Sullivan argued, 'a striking similarity' between humanist rhetoric and 'the method used by the Aztecs, and this similarity could not have escaped the friars'. 35 Rather than merely noticing this similarity, however, the mendicants amplified it in their translation and use of the Huehuetlahtolli. As we will see, moreover, the Tlatelolcan editors actually reshaped the style and arguments of the Nahuatl orations to enhance their neo-classical qualities. Franciscans did not invent the 'speech of the ancients' but they certainly initiated its transformation and dissemination in order to defend the indios' capacities and their mission.

\section{Liberal education and the Colegio de Santa Cruz, Tlatelolco}

The propagators of the Huehuetlahtolli had close ties to Tlatelolco. Sahagún and Olmos were among the first Latin masters at the Colegio de Santa Cruz and Bautista and Torquemada were guardians of the Convent de Santiago. ${ }^{36}$ The college was managed for much of its history by indigenous alumni, but it lost vice-regal support in ${ }_{15} 64$ and was returned to Franciscan oversight in I570. At any time, in its prime, it was liberally educating between 60 and Ioo sons of caciques, a term used by the Spanish for indigenous leaders. ${ }^{37}$ This much is well established. The debt that the college's intellectual culture owed to Erasmus of Rotterdam is less frequently recognised. Erasmians were persecuted in Spain after I543 and in Mexico in the I570s, particularly. ${ }^{38}$ There is evidence to suggest, however, that the humanist's pedagogical influence endured at Tlatelolco. In addition to furnishing the ladinos with a grammatical and rhetorical

${ }^{35}$ Sullivan, 'The Rhetorical Orations, or Huehuetlahtolli', 83.

${ }^{36}$ Sahagún, Florentine Codex, I, 82; Mendieta, Historia, IV.I5, 4I4-I8; Torquemada, Monarquía Indiana, V (I5:43), I74-9; Louise Burkhart, Holy Wednesday: A Nahua Drama from Early Colonial Mexico (Philadelphia, I996), 55-65, 68-9; Robert Ricard, The Spiritual Conquest of Mexico, trans. Lesley Bryd Simpson (Berkeley, I966), 218-24; Lino Gómez Canedo, La educación de los marginados durante la época colonial: Escuelas y colegios para indios y mestizos en la Nueva España (Mexico, I982), I3I-2I5; Kobayashi, La educación como conquista, 2I4-I6.

37 Códice de Tlatelolco in Códice Mendieta: documentos Franciscanos siglos XVIy XVII, ed. Joaquín García Icazbalceta (2 vols., Mexico, I892), II, 24I-9; Andrew Laird, 'Teaching of Latin to the Native Nobility in Mexico in the Mid-I5oos: Contexts, Methods, and Results', in Learning Latin and Greek from Antiquity to the Present, ed. Elisabeth P. Archibald, William Brockliss and Jonathan Gnoza (Cambridge, 2015), II8-35; SilverMoon, 'The Imperial College of Tlatelolco and the Emergence of a New Nahua Intellectual Elite in New Spain (I500-I760)' (Ph.D., Duke University, 2007).

$3^{8}$ Marcel Bataillon, Erasmo y España: estudios sobre la historia espiritual del siglo XVI, trans. Antonio Alatorre (2 vols., Mexico, I950), II, 31 I-55, 435-54; Martin Austin Nesvig, Ideology and Inquisition: The World of the Censors in Early Mexico (New Haven, 2009), and idem, 'The Epistemological Politics of Vernacular Scripture in Sixteenth-Century Mexico', The Americas, 70 (2013), I65-20I. 
tool kit, Erasmus's works may have informed their intellectual activities, including their work on the Huehuetlahtolli.

The initial impulse for founding the Colegio de Santa Cruz may have been the creation of an indigenous clergy. ${ }^{39}$ Yet well before I555, when the first church council of New Spain determined against native or mestizo ordination, the purpose of the school had broadened. $4^{{ }^{\circ}}$ The Tlatelolcans' enthusiasm for Erasmus's spiritual and pedagogical writings contributed to the process. In sixteenth-century Europe, Erasmus's jibes at the friars' expense had not gone unnoticed. Spanish Franciscans joined with other mendicant orders in submitting a list of Erasmus's errors in biblical scholarship and theology to the convenors of the Valladolid Assembly in $1527.4^{\mathrm{I}}$ Nevertheless, within the observant friars in Spain, many were drawn to aspects of Erasmus's work. Franciscans at the University of Alcalá, founded by the observant friar and archbishop of Toledo, Francisco Jiménez de Cisneros (I436-I5I7), used Erasmus's pedagogical works to hone their Latin. Some Alcalán Franciscans, including Fray Francisco de los Ángeles Quiñones (I482-I540), engaged critically with Erasmus's New Testament scholarship. ${ }^{22}$ A number of Franciscans associated with the alumbrados, mysticism and the devotio moderna drew on Erasmus's spiritual writings for their Christocentricity, criticisms of superstition, praise of apostolic simplicity and calls for ecclesiastical reform. Indeed, contemporaries often conflated Erasmianism with these other strands of spiritualism in sixteenth-century Spain. ${ }^{43}$

The first twelve Franciscans who travelled to New Spain in I524 were observant friars who practised apostolic poverty and contemplative piety. They were instructed by Quiñones, who became commissary general of the order in 1523.44 Once the Franciscans began their New World missions, Erasmus's Christocentric and scriptural account of faith proved

\footnotetext{
${ }^{39}$ Rodrigo de Albornoz to Charles V, I5 Dec. I525, in Colección de documentos para la historia de México: versión actualisada, ed. Joaquín García Icazbalceta, on www.cervantesvirtual.com; Toribio de Benavente Motolinia, History of the Indians of New Spain, ed. Francis Borgia Steck (Washington, DC, I95I), 297.

$4^{\circ}$ Don fray Juan de Zumárraga, ed. Icazbalceta, III, 204; Andrew Laird, 'Latin in Cuauhtémoc's Shadow: Humanism and the Politics of Language in Mexico after the Conquest', in Latinity and Alterity in the Early Modern World, ed. Yasmin Annabel Haskell and Juanita Feros Ruys (Tempe, AZ, 2010), I69-99, 274-6.

${ }^{4 \mathrm{I}}$ For example, Erasmus, CWE, XXVII: Praise of Folly, ed. A. H. T. Levi (Toronto, I986), I3I-5, and CWE, XL: Colloquies, ed. Craig R. Thompson (Toronto, I997), 763-95. On the Franciscan response, see Lu Ann Homza, 'Erasmus as Hero, or Heretic? Spanish Humanism and the Valladolid Assembly of I527', Renaissance Quarterly, 50 (I997), 78-I I8, at 82-4.

$4^{2}$ Bataillon, Erasmo y España, I, I-59, I8I, 326, 368, 405-7; Massimo Firpo, fuan de Valdés and the Italian Reformation, trans. Richard Bates (Farnham, 20I5), 6-25.

${ }^{43}$ Bataillon, Erasmo y España, I, I9o, 206-2 I, 368-424; José C. Nieto, 'Luther's Ghost and Erasmus' Masks in Spain', Bibliothèque d'Humanisme et Renaissance, 39 (I977), 33-49.

${ }^{44}$ Bataillon, Erasmo y España, II, 445-6; Steven Turley, Franciscan Spirituality and Mission in New Spain, 1524-I599: Conflict beneath the Sycamore Tree (Luke I9:I-IO) (Farnham, 2014), 24-49.
} 
useful for tackling indigenous idolatry. In New Spain, moreover, his support for vernacular preaching and scripture sounded like practical solutions to the challenges of evangelisation rather than the germs of Lutheranism. Juan de Zumárraga, the Franciscan, first bishop of Mexico and co-founder of Santa Cruz drew on Erasmus's Paraclesis (I5I6) and Enchiridion (I5OI) to make these arguments in his Doctrina breue (I544) for catechising the indios. ${ }^{45} \mathrm{He}$ excerpted Erasmus's defence of turning scripture 'into all the languages of the world, not only that it might be read by the Indios, but also that all other barbarous nations may read and know' it too. ${ }^{6}$ Zumárraga owned at least fourteen of Erasmus's works, including his Paraphrases on Luke and On the Apostolic Letters. ${ }^{47}$ The bishop used Erasmus's writings to emphasise the spiritual and civic benefits that elite laymen in the Americas could derive from studying classical texts and scripture. Rather than churning out candidates for ordination, Erasmus's bonae litterae could prepare noble Nahuatl youths to be faithful magistrates in the localities, champions of the gospel and moral exempla in New Spain.

Santa Cruz's commitment to vernacular scripture and the liberal education of indigenous students survived Zumárraga. Indeed, their interest in Erasmus persisted, despite the placement of all his writings on the Tridentine Index of 1559 , fourteen of them on the Spanish Index of 1559 , the prohibitions and expurgations listed in Gaspar de Quiroga's Indices of 1583 and ${ }_{1584}$ and the blanket ban in I6I2. In I57I, Pedro Moya de Contreras (c. I528-9I), the first inquisitor general and third archbishop of Mexico, ordered a general purge of prohibited books in his diocese. Bibles, Erasmus's works (predominantly the Adagia) and Zumárraga's Erasmian Doctrina dominated the haul from convents and clerics..$^{8}$ New evidence, however, from books in the convent library at Tlateloco shows that the Franciscans managed to save some editions of Erasmus. The front matter of their copies of Erasmus's Life of Origen and Erasmus's edition of Hilary's (d. 367?) Lucubrationes, were expurgated, since they were 'full of heresies and impiety'. Yet the convent retained the texts themselves, even after i6r2. Not only did the Tlatelolco's copy

\footnotetext{
${ }^{45}$ Bataillon, Erasmo y España, I, I3 ${ }^{\mathrm{I}-2, \text { II, 445-5 }}$ I; Andrew Laird, 'Classical Letters and Millenarian Madness in Post-Conquest Mexico: The Ectasis of Fray Cristóbal Cabrera', International Fournal of the Classical Tradition, 23 (2016), I-3 I.

${ }^{46}$ estuviessen traduzidas en todas las lenguas de todos los del mundo para que no solamente las leyessen los Indios: pero aun otras naciones barbaras: leer y conocer': Juan de Zumárraga, Doctrina breue muy p[ro]uechosa delas cosas q[ue] p[er]tenecen ala fe catholica y a n[uest ra cristiandad en estilo llano p [ar] a comu[n] intelige[n]cia (Mexico: Juan Cromberger, I544), sigs. Kviir, Kviiir (quotation). Cf. Erasmus, Paraclesis (Basel: J. Froben, I5I9), 7-8.

47 Zumárraga and his Family: Letters to Viscaya, ed. Richard Greenleaf (Washington, DC, I979), I22-6.

${ }^{4}$ Libros y libreros en el siglo XVI, ed. Francisco Fernández de Castillo, 2nd edn (Mexico, I982), 473-95; Henry Kamen, The Spanish Inquisition: A Historical Revision (New Haven, 2014), I26, I32-3; Nesvig, Ideology and Inquisition, 5, II9-22, I45-7, I5I, 233, 235.
} 
of Erasmus's edition of Arnobius's commentary on the Psalms survive unmolested but Erasmus's prefatory material was annotated approvingly by a sixteenth-century clerical reader. ${ }^{49}$ This pattern suggests they may have retained other works, too. By sticking with Erasmus, the Tlatelolcan Franciscans do not seem to have been trying to be obstreperous. Their attitude to the deliberately subversive Erasmian, fray Alonso de Cabello (c. I555-83), who used Erasmus's writings to criticise the rules of his order, is suggestive. The convent assumed responsibility for Cabello's house arrest while he was under Inquisitorial investigation in 1576 and 1577 , yet he seems to have had access to Erasmus's works in his cell. ${ }^{\circ}$ Tlatelolcan friars could see the danger posed by Cabello's sermons but they did not necessarily blame his source texts.

The college adopted and probably kept using Erasmus's grammatical and rhetorical works because they were fit for purpose. Material from the northern humanist's Libellus de octo orationis partium constructione (I5I3), Formulae colloquiorum familiarium ( $\mathrm{I}_{5} \mathrm{I} 8$ ), De conscribendis epistolis (1522) and De copia (I5I2) filled fray Maturino Gilberti's Grammatica (I559), the first Latin grammar printed in New Spain. Gilberti and his publisher were confident that they could sell textbooks in Mexico by openly declaring that 'the works of Erasmus demonstrate no small degree of learning' ${ }^{5}$ ' Treatises by Erasmus's pedagogical ally, Juan Luis Vives, were also popular. Indeed, demand for his Exercitationes linguae latinae (I539) was sufficient that Francisco Cervantes de Salazar (c. I514-c. I575), the first professor of rhetoric at the Real y Pontificia Universidad de México, produced a Mexican edition in I554. He supplemented it with three Latin dialogues about the New World, the second of which described and commended the Colegio de Santa Cruz. ${ }^{52}$ Cross-referencing I57I and 1574 inventories of Santa Cruz, surviving items from the library at Tlateloco and indigenous students' compositions confirms that Erasmus's prescriptions guided Nahua students through Aesop's Fables, Cato's Disticha

49'que heresib[us] \& impietate erat plena': annotation on the verso of the frontispiece, Hilary, Lucubrationes, ed. Desiderius Erasmus (Basel: J. Froben, I535), Sutro Library, San Francisco, Vault, BT25 .H54 I535; Origen, Opera, quae quidem extant omnia, ed. Desiderius Erasmus (Basel: Froben, I557), Sutro Library, San Francisco, Vault, BT25 .O74 L3 I557; Arnobius, Commentarij, pr[i]iuxta ac eruditi in omnes psalmos sermone Latino, ed. Desiderius Erasmus (Basel: Hieronymus Froben and Nicolaus Episcopius, 1537), Sutro Library, San Francisco, Vault, B65o .A $76_{3} \mathrm{I}_{5} 6$ I537.

${ }^{\circ}$ Martin A. Nesvig, Forgotten Franciscans: Writings from an Inquisitional Theorist, a Heretic, and an Inquisitional Deputy (University Park, PA, 201 I) 7-8, 22, 56, 56-8, and idem, 'The Epistemological Politics', I92-4.

${ }^{5}$ Maturino Gilberti, Grammatica Maturini: Tractatus omnium fere qu[a]e Grammatices studiosis tradi solent, ed. Rosa Lucas González (2 vols., Zamora, 2003), I, 2I-3, 63, 310-II, II, 530 (quotation), 598-717; Nesvig, Ideology and Inquisition, 122-3.

${ }^{52}$ Francisco Cervantes de Salazar, Commentaria in Ludovici Vives exercitationes linguae latinae (Mexico: Juan Pablos, I554). 
and works by Virgil and Cicero. ${ }^{53}$ Given the many copies of Erasmus's Adagia owned by friars and convents before I574 (and possibly after), it seems likely that the ladinos extracted commonplaces from them to enliven their Latin compositions. ${ }^{54}$ Next, Erasmus recommended that students read the Proverbs of Solomon and Ecclesiasticus. The I577 debates about the Nahuatl translations of both these texts, which climaxed in the prohibition of fray Luis Rodríguez's indigenous version of Proverbs, suggests that the colegiales did just that. ${ }^{55}$ Erasmus proposed that one of the most important exercises for enhancing students' speech and their capacity to explicate rich concepts was translation between tongues and across genres..$^{6}$ Tlatelolco's ladinos performed this exercise by translating Christocentric devotional works that encouraged personal piety and the preeminence of the spirit over the flesh. Scripture and Erasmus's spiritual writings almost certainly featured but the Franciscans prudently advertised their students' familiarity with less controversial texts. In I570, for instance, Mendieta presented Juan de Ovanda (I5I5-75), president of the Council of the Indies, with a Nahuatl rendering of Thomas à Kempis's De imitatione Christi (1424-7). This classic of the devotio moderna was often associated with Erasmus's Enchiridion militis Christiani (I5OI), but spared its infamy. 57

Under this Erasmian regime, the students' progress in grammar and rhetoric impressed their teachers and confounded detractors. ${ }^{5^{8}}$ In October I584, for instance, Alonso Ponce (fl. I584-92), the proposed Franciscan commissary general for the New World and an opponent of teaching indigenous boys grammar, visited the college. The students greeted him with Latin orations in which they protested their inability, as indios, to speak good Spanish. Tlatelolco's annotated copy of the Institutio oratoria (8.6.54-5) suggests that Quintilian's lesson on irony had not been

53 Códice Mendieta, II, 255-6, 259-6I; Aesop in Mexico: die Fabeln des Aesop in Aztekischer sprache, ed. G. Kutscher, G. Brotherston and G. Vollmer (Berlin, I987); Laird, 'Teaching of Latin to the Native Nobility in Mexico in the Mid-I50os', I27 n. 37.

${ }^{54}$ Libros y libreros, ed. Fernández del Castillo, 476, 485-7, 493-5.

55 Nesvig, Ideology and Inquisition, I53-7; David Tavárez, 'A Banned Sixteenth-Century Biblical Text in Nahuatl: The Proverbs of Solomon', Ethnohistory, 6o (2013), 759-62. Cf. Erasmus, CWE, xxxIx: Colloquies (Toronto, I997), I84, and idem, Education of a Christian Prince, trans. N. M. Cheshire and M. J. Heath, ed. Lisa Jardine (Cambridge, I997), 6I.

${ }^{56}$ Erasmus, CWE, XxIv: De copia, De ratione studii, ed. Craig R. Thompson (Toronto, I978), 306.

${ }^{57}$ David Tavárez, 'Nahua Intellectuals, Franciscan Scholars, and the devotio moderna in Colonial Mexico', The Americas, 70 (2013), 203-35, at 203-5, 2I0-II; Bataillon, Erasmo y España, I, 57, 240-51.

${ }^{5}$ Julián Garcés, 'Humanism and the Humanity of the Peoples of the New World: De habilitate et capacitate gentium (I537)', ed. and trans. Andrew Laird, Studi umanistici Piceni, 34 (2014), I83-226; Ignacio Osorio Romero, Le enseñaza del latín a los indios (Mexico, I990), $26-8$. 
lost on the ladinos. ${ }^{59}$ Erasmus's curriculum was producing results in the New World. The gramaticos learned 'to instruct others in the schools of their towns... to translate from Spanish or Latin ecclesiastical matters, [and] to serve as interpreters for the Audiencias'. They prepared to serve as 'judges and governors, and to [undertake] other duties in the republic'. ${ }^{6}$ Finally, Erasmus taught boys how to translate devotional works, sermons and scripture, an activity that Tlatelolcan friars lobbied (in vain) to continue when they resumed responsibility for Santa Cruz in the ${ }^{\text {I570s. }}{ }^{61}$

The Franciscans praised their former students for their intellectual and literary contributions to evangelisation and the huehuetlahtolli. Sahagún identified Martín Jacobita of Tlatelolco, Alonso Vergerano and Pedro de San Buenaventura of Cuautitlán for their contributions to Book VI of the Florentine Codex. In particular, these trilinguales 'amended, explained, and expanded' the orations. ${ }^{62}$ Juan Bautista similarly praised Santa Cruz's ladinos. Hernando de Ribas (d. I597) had 'written and translated over 30 quires of paper on diverse things for [Bautista]'. Don Juan Berardo (d. I594) and Don Francisco Baptista de Contreras served as native governors, writers and translators. Diego Adriano of Tlatelolco had 'learned to compose and to set type for the printing press in any language'. 63 Estevan Bravo of Texcoco wrote in Latin, Spanish and Nahuatl and was notable for copia, a rhetorical virtue in all three tongues. Pedro de Gante (d. I605), native of Tlatelolco, had taught at Santa Cruz and translated the lives of saints for Bautista. Finally, Agustin de la Fuente, college master during Bautista's guardianship, had 'gone over everything that [Bautista had] printed here'. He had also learned to compose sermons and composite type in order to correct missionary texts. ${ }^{6}$ 'The ladinos' Erasmian education had made them textual editors,

${ }^{59}$ Quintilian, Oratoriarum institutionum libri I2 (Paris: Nicolaus Savetier, I527), Sutro Library, San Francisco, Vault, PA6649 .A2 I527; Antonio de Ciudad Real, Tratado curioso y docto de las grandezas de la Nueva España, ed. Josefina García Quintana and Victor M. Castillo Farreras (2 vols., Mexico, I976), I, I6-I7.

${ }^{60}$ 'los indios que salen deste colegio de enseñar á otros en las escuelas de sus pueblos ... y interpretar en ella las cosas eclesiásticas que se vuelven de latín ó romance, y asimismo sirven de intérpretes en las Audiencias... se suelen encomendar los oficios de jueces y gobernadores y otros cargos de república': Códice Mendieta, I, i78.

${ }^{6}$ I Torquemada, Monarquía Indiana, V (15:43), I75; Sahagún, Florentine Codex, I, 83 ; Motolinia, History of the Indians of New Spain, 38; Códice Mendieta, I, 72-3; Burkhart, Holy Wednesday, 65-73; Gómez Canedo, La educación de los marginados, I8o-8; Nesvig, 'The Epistemological Politics'; Tavárez, 'Nahua Intellectuals'.

${ }^{62}$ Sahagún, Florentine Codex, I, 44, 54-5.

${ }^{6}$ ' $\mathrm{el}$ qual me escriuio, y traduxo de cosas diuersas mas de treynta manos de papel' and 'aprendio acomponer, y componia en la Emprenta en qualquier lengua': Juan Bautista, 'Prologo', A Iesu Christo S.N. ofrece este sermonario en lengua Mexicana (Mexico: Diego Lopez Davalos, i6o6), sig. *VIIv.

64 'passado todo quanto he impresso hasta aqui': Bautista, 'Prologo', Sermonario, sigs. ** Ir (quotation), ${ }^{*}$ VIIIr- ${ }^{* *}$ Ir. 
translators and persuasive speakers, and prepared several to serve as Christian governors in New Spain.

The gramaticos' liberal educations may have encouraged them to collaborate on the Huehuetlahtolli. Don Antonio Valeriano of de Azcapotzalco (I526?-I605) was 'the principal and wisest' of Sahagún's collaborators on the Florentine Codex and praised by Bautista for 'speaking Latin ex tempore with so much propriety and elegance that he seemed another Cicero or Quintilian'. ${ }^{6}$ After completing his studies at Santa Cruz, Valeriano remained at the college, first as a Latin lector and then as the rector. He translated Cato's Disticha into Nahuatl for the students, assisted Alonso Molina with the Vocabulario en lengua castellana y Mexicana ( 555, I57I) and collaborated with Juan de Gaona on a set of Erasmian Colloquios de la paz y tranquilidad christiana en lengua Mexicana (I582). Valeriano was an editor of the Florentine Codex and contributed to Sahagún's Los coloquios de los doce, and Primeros memoriales. He provided Spanish glosses for Bautista's I6o6 collection of Nahuatl sermons. It seems likely that he also worked on the Huehuetlahtolli ${ }^{66}$ What motivated his intellectual activities?

Valeriano was probably aware that his liberal education facilitated his success in colonial government. After serving on the cabildo of Azcapotzalco, he married Doña Isabel de Alvarado, the daughter of the first judge-governor of Tenochtitlan. Valeriano was elected to that office himself in I573. Don Antonio was not humbly born but the indigenous chronicler, Fernando Alvarado Tezozmoc, also associated his status as a tlatoani, or ruler, with his wisdom - he was a tlamatini or 'one who knows things' ${ }^{67}$ Valeriano served the Spanish empire but he was not a craven puppet. In February I56r, he petitioned Philip II on behalf of Azcapotzalco for exemptions from labour and tribute, the restitution of lands, the translation of their city's status from town to city (oppidum to civitas) and permission to establish a traditional market (tiyanquiliztli). These were typical cacique demands but Valeriano expressed them in good Latin and warranted his appeal by referring to Acapotzalco's 'antiquity and nobility'. He added a more unusual request, too, a licence to establish

\footnotetext{
$6_{5}$ 'hablaua ex tempore... con tanta propriedad, y elegancia, que parecia un Ciceron, o Quintiliano': Bautista, 'Prologo', Sermonario, sig. *VIIIr-v; Sahagún, Florentine Codex, I, 54-5.

${ }^{66}$ Cervantes de Salazar, Commentaria in Ludovici Vives, fo. 276r; Bautista, 'Prologo', Sermonario, sig. *VIIIr-v; Sahagún, Florentine Codex, I, 83-4, and idem, Coloquios y doctrina cristiana: con que los doce frailes de San Francisco, enviados por el papa Adriano VI y por el emperador Carlos V, convirtieron a los indios de la Nueva España, ed. Miguel León-Portilla (Mexico, I986), 75; Torquemada, Monarquía Indiana, v (I5:43), I76-7; Burkhart, Holy Wednesday, 66, 68-70, 73; Gómez Canedo, La educación de los marginados, I66.

${ }^{67}$ Fernando Alvarado Tezozomoc, Crónica mexicáyotl, ed. Adrián León (Mexico, I975), I76; María Castañeda de la Paz, 'Historia de una casa real: origen y ocaso del linaje gobernante en México-Tenochtitlan', Nuevo Mundo Mundos Nuevos (2011), http://nuevomundo.revues.org/60624; William F. Connell, After Moctezuma: Indigenous Politics and Self-Government in Mexico City, $1524-1730$ (Norman, OK, 201 I), 55, 60.
} 
a 'house of the muses' for teaching '[Latin] grammar and Spanish'. 'These [tongues]', Valeriano explained, 'may be taught conveniently by some of us [Nahua], who have professed Latin frequently, and as well as the Spanish.' 68 The letter was suitably unctuous but it also asserted its author's intellectual and cultural parity. As governor of Tenochtitlan, Valeriano continued to fight with his pen. In I575, he roused a crowd of several thousand indios to protest at Spanish interference in the Convent de Santiago's jurisdiction over the nuns of Santa Clara. In I578, he complained to Philip II again, this time about the ignorance of the secular clergy. 'Most of them have no languages, the rest know [too] little, and they do not preach to the indigenous', he fumed. ${ }^{69}$ Like Erasmus and the Tlatelolcan friars, he insisted on the effectiveness of evangelisation in the vernacular.

Valeriano's instruction at Santa Cruz had rendered him a sincere Christian, loyal to the friars, and ready to participate in imperial government. By urging him to write in Nahuatl and for the Nahua, however, his teachers had fostered his native cultural knowledge and affinities. As Valeriano told Philip II, he had learned to be both 'cacique y gobernado'.$^{70}$ In Erasmus's account of the responsibilities of rulers to advance the spiritual welfare of their subjects, moreover, Don Antonio may have found a model for reconciling his dual identities. He could use his trilingual rhetorical skills and his knowledge of the normative power that the past possessed for Europeans and Nahuas to advocate for the religious and moral education of the indios. Alumni like Valeriano may have collaborated with Bautista on the Huehuetlahtolli for the same reason that they defended Santa Cruz; the institution and its ancient texts offered indigenous boys opportunities for advancement, devotion and the preservation of Nahuatl culture in the new (colonial) world.

By the I590s, the college needed support from alumni like Valeriano. It had been struggling for more than fifteen years. Sahagún lamented

\footnotetext{
${ }^{68}$ 'antiquitate et nobilitate', 'iudicamus nos etiam musarum domo donari debere $\ldots$ at certe grammatica cum lingua Hispana quae commodius praelegi possunt a quibusdam nostri qui sermonem Latinum perinde ac Hispani saepe sunt professi': Alcaldes and regidores of Azcapotzalco to Philip II, Io Feb. I56I, in La nobleza indígena del centro de México despues de la conquista, ed. Emma Pérez-Rocha and Rafael Tena (Mexico, 2000), 218, 222; Andrew Laird, 'Nahuas and Caesars: Classical Learning and Bilingualism in Post-Conquest Mexico; An Inventory of Latin Writings by Authors of the Native Nobility', Classical Philology, Io9 (2014), I50-69, I57-6o. On native governors, see Peter Villella, Indigenous Elites and Creole Identity in Colonial Mexico, I500-180o (Cambridge, 2016), 37-9, 85-6.

${ }_{69}^{6}$ 'Porque los más dellos no eran lenguas, y algunos que lo eran sabían poco y no predicaban a los naturales': Don Antonio Valeriano, letter to Philip II, I578, in Miguel León-Portilla, 'Una carta inédita de don Antonio Valeriano, I578', Estudios de cultura Náhuatl, 49 (2015), 199-207. For Valeriano's attempts to protect the convent, see Archivo General de Indias, Seville, Mexico 283, fos. 20v, 3ov-36r.

${ }^{70}$ Valeriano, letter to Philip II, in León-Portilla, 'Una carta inédita', 206.
} 
that it had lost its income-generating estates to the mismanagement of the Spanish majordomo, Diego Ruiz, and its good order to 'the negligence... of the rector', the counsellors and friars. The greatest blow, however, was the plague of 1576 , which killed many of the college's pupils. ${ }^{7}{ }^{1}$ In this weakened state, Santa Cruz faced Archbishop Moya de Contreras's renewed criticisms of the Franciscan's educational mission, especially the Latin instruction of the indios. Indeed, by Sahagún's death in I590, Santa Cruz's humanist curriculum had atrophied. ${ }^{72}$ When Bautista became the guardian of the convent in 1597 , he involved alumni like Valeriano in his Nahuatl-language print campaign to revive the college's fortune. It was time, he argued, to reassert the importance of 'raising young people in the fear and love of Our Lord'. 'Consider', he wrote, 'on the one hand the lack of education, respect or regard, and the barbarity of speech, and the little policy of the native youth of these times, and, on the other, the careful education, civility, respect, courtesy, and good diction and elegant speech of the ancient natives. ${ }^{73}$ The text in which Bautista announced his campaign for vernacular education was the Huehuetlahtolli. The gramaticos brought their native knowledge of the 'speech of the ancient' Nahuas and their Erasmian study of the speech of the ancient Israelites, Greeks and Romans to bear on the project.

\section{Tlatelolco and the creation of the Huehuetlahtolli}

Georges Baudot argued influentially that when fray Juan Bautista discovered Andrés de Olmos's collection of Nahuatl orations, he deemed them a 'gift from God' and printed them expeditiously.74 In fact, the last six Nahuatl speeches in Bautista's Huehuetlahtolli, one of which is addressed 'to those who go to school or learn doctrine with the Religious in the Monasteries', indicate that Bautista initiated more

${ }^{71}$ Sahagún, Florentine Codex, I, 82-4, 92; Códice de Tlatelolco in Códice Mendieta, II, 250-I.

${ }^{72}$ Mendieta, Historia, IV:I5, 418; Torquemada, Monarquía Indiana, V (15:43), I76-7; Pilar Gonzalbo Aizpuru, Educación y colonisación en la Nueva España, I52I-I82I (Mexico, 200I), I207; SilverMoon, 'The Imperial College of Tlatelolco', 93-8; Burkhart, Holy Wednesday, 62-5; Kobayashi, La educación como conquista, 250-71; Gómez Canedo, La educación de los marginados, I88-95.

73 'criar a los niños enel temor y amor de nuestro Señor' and 'Considerando pues yo . . por una parte la poca criança, respecto y miramiento, barbaridad enel hablar, y poca policia de los Indios moçuelos deste tiempo, y por otra parte la mucha criança, urbanidad, respecto, cortesia, buen termino y elegancia enel hablar de los Indios viejos': Bautista, 'Prologue', in Huehuetlahtolli, sigs $\mathrm{p}^{*} 6 \mathrm{v},{ }^{*} 7 \mathrm{v}$.

${ }^{74}$ Baudot, Utopia and History in Mexico, 229-34; and Miguel León-Portilla, 'Estudio introductorio', Huehuetlahtolli: Testimonios de la antigua palabra, trans. Librado Silva Galeana, ed. Miguel León-Portilla (Mexico, I988), I4-19, which influenced Louise Burkhart, The Slippery Earth: Nahua-Christian Moral Dialogue in Sixteenth-Century Mexico (Tucson, I989), I024, I73-4, I79, despite this study's broader and ground-breaking argument for the mutual contamination of Nahua religion and Christianity. 
extensive augmentation and inventio. With a circle of ladinos, he adapted the 'old words' for their colonial, Christian context. 75 Scholars have begun to recognise the syncretic style and evangelising purpose of the printed Huehuetlahtolli. ${ }^{76}$ By contextualising the collection in the Erasmian pedagogy of Santa Cruz, however, we glean a sharper sense of the rhetorical tools that Olmos, Bautista and the ladinos collaborators used to enhance the force of the orations for novices and indigenous readers. We are also better able to discern the contours of the theory of speech that animates the printed collection.

Andrés de Olmos gathered only eight of the twenty-nine speeches printed in I6or but his 547 Arte de la lengua Mexicana showed Bautista how huehuetlahtolli could extend the rhetorical lessons of Nahuat--Spanish grammars and vocabularies for evangelising purposes. Olmos attached a speech, 'Of a father to his son', and the son's reply, to his Arte, and Bautista printed them with only slight modifications. The friar asked his indigenous collaborators to substitute the name of God verdadero for traditional Nahuatl deities in the huehuetlahtolli. 77 The result is that the father and son of the speeches venerate a single, personalised deity, 'Our Lord', Totecuyo and Ipalnemohuani, 'Giver of Life' or 'by whom one lives', an epithet for God favoured by mid-century Franciscans. ${ }^{78}$ Further, Olmos and his collaborators inserted passages that taught readers and auditors how to worship the Christian deity. 'When you pass before the venerable image of Our Lord, or his loved ones, or of the cross, (cruz)', the father counselled, 'you should bow before Him or bend the knee and much more if you go before the venerated body of Our Lord Jesus Christ (Iesu Christi), that is before the Holy Sacrament (isanto sacramento)'. ${ }^{79}$ Olmos understood the potential of huehuetlahtolli to lure new Christians back to old, idolatrous ways. ${ }^{80}$ By cleansing the Nahua antiquities of idolatry and

75 'In nonotzaloca immomachtia teupan, in quenin huel quimotlayecoltilizque Dios', Huehuetlahtolli, ed. Bautista, fos. 54r, 6or (quotation), 67r, 69v, 7Ir, 73r. Sahagún also noted the evangelising potential of the huehuetlahtolli: Adiciones, apéndice a la postilla y ejercicio cotidiano, ed. Arthur J. O. Anderson and Miguel León-Portilla (Mexico, I993), I05.

${ }^{76}$ Ruiz Bañuls, El huehuetlahtolli, I27.

77 Zorita, Relación de la Nueva España, ed. Ahrndt et al., 209; 'Exhortación', ed. García Quintana, I37-82; Huehuetlahtolli, ed. Bautista, fos. Ir-I4r (Nahuatl), fos. 77v-82r (Spanish).

${ }^{78}$ See Susanne Klaus, Uprooted Christianity: The Preaching of the Christian Doctrine in Mexico, Based on Franciscan Sermons of the Sixteenth Century Written in Nahuatl (Bonn, I999), I44.

79 'Ihuan in canin ixpantiquisaz in ixiptlatzin in Totecuiyo, ahnozo in itlazohuan, ahnozo cruz, huel ticmahuiztiliz: ixpan timopachoz ahnozo timotlancuacoloz. Auh intla huel yehualt in Totecuiyo Iesu Christi in inacayotzin, isanto sacramento, ixpan tiquisaz, tlapanahuia': 'Exhortación', ed. García Quintana, I52. With minor variations in Huehuetlahtolli, ed. Bautista, fo. 2r-v.

${ }^{80}$ See Andrés de Olmos, Tratado de hechicerías y sortilegios [I553], ed. Georges Baudot (Mexico, I990), 89. 
enhancing their evangelising content, he showed the friars how to deploy the orations as weapons for spiritual conquest.

The friars and collaborating gramaticos also made accommodations in the Huehuetlahtolli to explain Christianity to Nahua readers and auditors. For instance, the father of the first speech explained to his son that, 'God is your very mother, your father. [He] strives greatly to take good care of you. ${ }^{81}$ While sixteenth-century spirituali occasionally compared God to a nursing mother, it is unlikely that the dual-sex deity of this difrasismo is of European origin. ${ }^{82}$ Traditional Nahuatl prayers, spoken during childbirth, frequently invoked a divine pair, 'Our Mother, Our Father, the two lord and two lady' who had power over human generation. ${ }^{83}$ One might assume that the editors had simply missed this reference to the old gods when they Christianised the speech but they knew it was there. They cleansed the Spanish-language version of its feminine aspect, leaving a conventional sentiment '[God] raised you to help you, for he is your Father. ${ }^{84}$ This suggests that indigenous gramaticos had retained, or even added, the 'mother, father' couplet to explicate the life-giving power of the Christian God for Nahua students. Olmos and his collaborators may have made the 'speech of the ancients' sound Christian, but the inventio of the native linguists also made Christianity sound more like Nahuatl. ${ }^{85}$

Mónica Ruiz Bañuls has shown that Olmos, Bautista and their collaborators increased the evangelising potential of the huehuetlahtolli by interpolating biblical proverbs into the texts. They drew especially heavily on the Books of Proverbs and Sirach (or Ecclesiasticus), which Erasmus had prescribed for future rulers and which the gramaticos studied at Santa Cruz. The Vulgate places that they wove into the speeches described the duties of piety and filial obedience, the dangers of lust, intoxication

\footnotetext{
${ }^{81}$ 'Ca yehualt Dios, huel monantzin, motatzin; icenca, tlapanahuia': 'Exhortación', ed. García Quintana, I52; with minor variations in Huehuetlahtolli, ed. Bautista, fo. Iv.

${ }^{82}$ In her Meditations on the Song of Songs, for instance, Teresa of Avila ( $\left.15^{1} 5^{-82}\right)$ followed Ramon Llull and compared the human soul to a baby and God to a 'mother who loves her baby, nourishes it, and attends to it': Teresa of Avila, Obras completas de Santa Teresa, ed. Efrén de la Madre de Dios and Otger Steggink (Madrid, I986), 452. Nevertheless, this metaphor was far from orthodox during the Catholic Reformation. Indeed, fray Luis de Léon left Teresa's Meditation out of his I588 edition of her works. Vernacular interpretations of the Song of Songs had been proscribed by the Council of Trent and Luis had been imprisoned from 1572 to I575, partly for circulating a Spanish version himself: Proceso inquisitorial de Fray Luis de León, ed. Ángel Alcalá (Valladolid, I99I), 221, 376-8.

${ }^{83}$ 'in ome tecutli, in ome ci[hualt]': Florentine Codex, ed. Sahagún, VII, I75. See Richard Haly, 'Bare Bones: Rethinking Mesoamerican Divinity', History of Religions, 3I (I992), 269304 , at 278 .

${ }^{84}$ '[Dios] te crio, que te ayude pues es tu Padre': Huehuetlahtolli, ed. Bautista, fo. $77 \mathrm{v}$.

${ }^{85}$ See, similarly, Mark Z. Christensen, Nahua and Maya Catholicisms: Texts and Religion in Colonial Central Mexico and Fucatan (Stanford, 2013); Burkhart, The Slippery Earth, 184-94.
} 
and gluttony, the need for self-discipline, the duties of officeholders and the inevitability of death. ${ }^{86}$ Strikingly, moreover, the gramaticos shaped the Nahuatl text to imitate the Vulgate Latin stylistically. Proverbs 4:I-4, for instance, begins with an exhortation:

Listen, my sons, to the instruction of your father and pay attention, so that you might learn prudence. I offer you good precepts; do not forsake my rules ... [4, My father] said to me 'Let your heart cling to my words and keep my precepts and you will live. ${ }^{87}$

In Latin, Proverbs 4:4 reads suscipiat verba mea ... custodi praecepta mea, a syntactical pattern of jussive subjunctive + plural neuter + first person possessive, then the same with an imperative verb, then a future indicative, et vives, to soften the command into a conditional. The Nahuatl oration 'Of the mother to her daughter' in the Huehuetlahtolli concluded with a very similar admonition:

If you do this, what I have spoken of, what I have instructed you, then truly you will live well, with people's favour, alongside the people. So I fulfil my duty ... Because you will never fall into error if you follow [this advice], if you listen, if you take it into your stomach, if you swallow it down your throat. ${ }^{88}$

In Nahuatl, the final phrase reads oticcuic intla moxillan, intla motozcatlan oticmopachilhui. It is a plaited pattern of preterit verb + conditional conjunction + possessed noun that mimics the syntax of the Vulgate proverb while incorporating a traditional Nahuatl couplet, 'into your stomach, down your throat'. The effect is to merge the prophetic tone and account of moral causation contained in the 'speech of the ancient' Israelites with the elevated tone and vivid, corporal imagery of traditional difrasismo. To the well-trained humanist, writing was 'most learned and eloquent' when it was sprinkled 'freely with adages'. ${ }^{89}$ By seasoning their huehuetlahtolli with Vulgate passages, the Tlatelolcans enhanced their evangelising potential and demonstrated the stylistic complementarity of Latin and Nahuatl. They also got away with printing some Old Testament proverbs in the vernacular.

The friars and ladinos did not merely integrate Vulgate passages. Rather, they adopted Erasmus's advice that an orator might vary proverbs

\footnotetext{
${ }^{86}$ Ruiz Bañuls, El huehuetlahtolli, i66-85. She notes that biblical proverbs also occur in Book VI of the Florentine Codex.

${ }^{87}$ 'audite filii disciplinam patris et attendite ut sciatis prudentiam/ donum bonum tribuam vobis legem meam ne derelinquatis . . . atque dicebat suscipiat verba mea cor tuum custodi praecepta mea et vives': Vulgate, Proverbs 4:I-4.

${ }^{88}$ 'Yntla yuh ticchihuazin inic onimitznonotz, inic onimitzizcali, yc nelli huel tinemiz in tepaltzinco, in tenahuactzinco. Yc mohuicpa ninoquixtia in nihuehue in nilama, in nitlacazcaltiani, in nitlacahuapahuani. Inic ahtle nahualoca yez in quemmanian intla otican, intla oticcac, intla oticcuic, intla moxillan, intla motozcatlan oticmopachilhui': Huehuetlahtolli, ed. Bautista, fo. 20v. See, similarly, Florentine Codex, ed. Sahagún, VII, 79, I05, II3.

${ }^{89}$ Erasmus, Adages of Erasmus, ed. William Watson Barker (Toronto, 200I), I I.
} 
syntactically or substitute their diction in order to explicate their meanings and ornament speech. For instance, the father of Sirach 4.7 urged his son: 'Address yourself courteously to the congregation of the poor, and humble your soul before the elders of the church, and bow your head before the great men.'90 When the editors of the Huehuetlahtolli interpolated this passage into the first speech of the father to the son they used the future tense in place of the imperative and maintained the ascending tricolon of identities that gave Sirach 4.7 its force. Nevertheless, they inverted the order of the original set, rendering it as, 'You will greet them ... the nobles ... the padres ... but also ... the humble. ${ }^{91}$ The effect was to emphasise the courtesy due to impoverished people, an appropriate sentiment for a Franciscan text.

Within this inverted tricolon structure, moreover, the Tlatelolcans made further elaborations. They took their strategies for copiousness from Erasmus's Familiarium colloquiorum formulae (I522), as it was relayed in the Mexican Grammatica Maturini. Erasmus began his instructions by telling schoolboys to greet others and by identifying the circumstances in which a salutation was appropriate: 'It is a mark of politeness (urbanitas) to greet those who meet us, or those we meet... likewise [to greet] those carrying out some work. ${ }^{\prime 2}$ The friars and ladinos followed their main verbal clause of instruction, 'You will greet them', with congruent details, 'anywhere they are going about their doings or simply where you will encounter them. ${ }^{93}$ Where Erasmus had used an active present participle + ablative construction (operis...agentes) for 'going about... work', the Tlatelolcans derived an equivalent with a possessed deverbalised noun + stative verb (itlachihul[huan] ... cate) for 'going about their business'. They showed Nahuatl's capacity to match the plenty and dignity of Latin, a desirable achievement among vernacular tongues in the renaissance, not least because it demonstrated the cultural and political sophistication of its speakers. ${ }^{94}$

Next, the Tlatelolcans ornamented the passage by synthesising elements of Nahuatl and European rhetoric. They inserted pairs of synonyms (los difrasismos) for the three sorts of people requiring salutation (the nobility, clergy and indigent) and used the particle ' $i n$ ' to connect them

\footnotetext{
$9^{90}$ 'Congregatione pauperum affabilem te facito, et presbytero humilia animam tuam, et magnato humilia caput tuum': Vulgate, Ecclesiasticus 4.7; Erasmus, Adages, I9-20.

$9^{1}$ 'Yhuan tiquintlahpaloz... in pipiltin ... in padreme $[\mathrm{h}] \ldots$ auh ... in ycnotlacatl': 'Exhortación', ed. García Quintana, I52-4; Huehuetlahtolli, ed. Bautista, fo. 2v.

${ }^{92}$ 'Urbanitatis est salutare obuios, qui nos adeu[n]t, aut quos adimus ... ite[m] operis aliquid agentes... ': Erasmus, Familiarum colloquiorum opus (Basel: Froben, [1522] I538), sig. A3r; Grammatica Maturini, ed. Lucas González, II, 598.

93'Yhuan tiquintlapaloz in itlachihualhuan in campa cate in ahnozo cana': 'Exhortación', ed. García Quintana, I52; with slight variations in Huehuetlahtolli, ed. Bautista, fo. 2v.

${ }_{94}$ Peter Burke, Languages and Communities in Early Modern Europe (Cambridge, 2004), 6I-88.
} 
syntactically and subordinate them to the main clause of the tricolon. Olmos's team explained that the 'nobles' were also 'rulers and those standing over the people' (in tlatoque yhaun in tepan ihcanime). To the category of padres, Bautista's team added 'religious leaders and prelates' (in teoyotica teyacanque in tepachohuanime). The meek, the largest class of persons, was distinguished by the new sentence particle, auh. It included 'the old man, the old woman', whose decrepitude (rather than wisdom) was suggested by mock reverential suffixes (in huehuentzin in ilamatzin), along with 'the humble and the lowly, the unhappy and the joyless'.95 Los difrasismos are the most important figure of Nahuatl rhetoric yet Erasmus also described synonyms as the 'first and simplest form' of copia. He followed Quintilian in encouraging schoolboys to 'collect a vast supply of words like this' so that they could deploy them in their speaking and writing..$^{6}$ By enhancing the Nahuatl platica, the editors displayed their own storehouses of los difrasismos. By putting them in print, the Tlatelolcans provided clerical and indigenous readers with sets of paired entries to start building their own rhetorical reed chests. With the Huehuetlahtolli, the ladinos used their knowledge of Latin grammar and rhetoric to demonstrate the powerful techniques of Nahuatl discourse for a colonial audience.

In explaining why eloquent Nahuatl was morally, politically and religiously valuable, the friars and gramaticos also drew on Erasmus's account of the nature and function of good speech. It is striking, for instance, that despite the Tlatelolcans' frequent recourse to Proverbs and Sirach in the Huehuetlahtolli, they avoided the (many) Old Testament adages that associated ready speech with moral degeneracy. 'Listen, children, to the doctrine of the tongue', the speaker of Sirach 23 warns in a representative passage, 'He who guards it shall not perish by his lips; he will not be led into sin by the most wretched deeds.' 97 In contrast, in the Huehuetlahtolli the father urges his son to address others 'by means of most elegant speech (huel qualli tlahtotica). You will not go about as if you are voiceless. ${ }^{98}$ Moreover, when the editors of the Huehuetlahtolli did draw on Sirach's prescriptions (5:I3-I7, 32:I0-I3), they adapted the proverbs to emphasise the benefits that accrued to civil speakers. For example, a father tells his son to be modest in the company of social superiors:

\footnotetext{
95 'yhuan in ycnotlacatl, in nentlacatl, in ahmo ahuiya, in ahmo paqui': 'Exhortación', ed. García Quintana, $152-4$; with the variation described in Huehuetlahtolli, ed. Bautista, fo. $2 \mathrm{v}$.

${ }^{96}$ Erasmus, CWE, XXIV, 307; Quintilian, Institutio oratoria, I0.I.6-7.

97 'doctrinam oris audite filii et qui custodierit illam non periet in labiis suis nec scandalisabitur in operibus nequissimis': Vulgate, Ecclesiasticus 23:7. See similarly Ecclesiasticus, 9:I3, I9:4-17, 20:4-5, 28:I3-26, and Proverbs, II:I3, I2:23, I4:23, I5:21, $28: 20$.

${ }^{98}$ 'huel qualli tlahtoltica. Ahmo yuquin tinontli yc tinemiz': 'Exhortación', ed. García Quintana, I54; Huehuetlahtolli, ed. Bautista, fo. 2v.
} 
If it is not your place to hold forth, you will not speak, you will not give orders, you will refrain [from talking]. If it is not your place to speak, and yet you are questioned, then you will speak prudently (zan melahuac), you will never tell lies, you will not disparage anyone. You will prepare your words very carefully (huel ticnehmachiliz) so that you do not answer like an idiot or like a braggart. When you do speak, when you answer, if you hang your words out swiftly, you will be honoured. ${ }^{99}$

Erasmus had evoked the same Vulgate authorities in a different order in his colloquy, Lesson on Manners (1522), for boys at a feast:

Your speech should not be foolish or hasty. Do not let your mind wander but pay attention to what is said. If a response is needed, make it concisely and prudently (paucis, ac prudenter)... Avoid loquaciousness, indeed you should not speak unless you are questioned... Don't disparage anybody, or make assumptions. Don't boast about your things, or belittle another's ... Don't slander anyone... You should not let your tongue wag idly. So it is, that without prejudice, you will win praise and make friends. ${ }^{100}$

Erasmus anticipated and possibly guided the ladinos in specifying the social circumstances that called for restraint and in concluding the Vulgate admonitions with a clause emphasising that good speech brought honour to the orator and strengthened civil bonds.

Indeed, qualli tlahtolli, the ladinos' phrase for 'good speech', was an exact Nahuatl cognate for Erasmus's preferred term, bonae litterae. ${ }^{\mathrm{IOI}}$ To qualify as 'good', Erasmus argued that speech had to emerge from the careful study of classical texts and scripture, imitate ancient usage (though not slavishly) and enhance the moral probity and religious devotion of orator and auditor. In an early epistle, Erasmus contended that good speech or letters 'were not conferred, like worldly honours, upon the idle and undeserving. They did not distract one from practising virtue but themselves conferred it . . without them we could not even be human. ${ }^{\text {'102 }}$ To be human meant to be drawn from the caves of the savages and into society, as Cicero had argued in De Inventione. For Erasmus, eloquence and virtue encouraged civility, concord and piety. As such, Erasmus argued

99 'in tlacamomo tlahtohuayan, ahmo tehuan titlahtoz ahmo tinahuatiz, zan timocahuaz. Auh intla no tehuatl motlahtohuayan, ahnozo titlatlaniloz, zan melahuac inic titlahtoz, ahtle tiquiztlacaihtoz, ayac ticchicoihtoz, huel ticnehmachiliz immotlahtol inic titlananquiliz, ahmo yuhquin tixolopitli, ahmo no yuhquin timopohuani inic titlahtoz inic titlananquiliz, zan tecpilhuetziz immotlahtol, yc timahuizoloz': Huehuetlahtolli, ed. Bautista, fos. 6v-7r.

Iоо 'Ne sis inepte loquax, aut praeceps. Ne uagetur animus interim, sed sis attentus quid ille dicat. Si quid erit respondendum, id facito paucis, ac prudenter ... Arride loquentibus: ipse ne quid loquaris, nisi rogatus... Ne cui obtrectato: ne cui temet ante ponito: ne tua iactato: ne aliena despicito ... Ne sis lingua futili. Ita fiet, ut sine inuidia laudem inuenias, \& amicos pares': Erasmus, Familiarum colloquiorum opus, sigs. C8v, Dir-v.

${ }^{\text {IOI }}$ The Nahuatl introductions to familial speeches in book six of the Florentine Codex, ed. Sahagún, VII, 93, 99, II3, also describe the discourse they announce as 'qualli in tlatolli', or 'good in speech'.

${ }^{102}$ Erasmus, CWE, I: Letters I to I4I (1484 to I500), trans. R. A. B. Mynors and D. F. S. Thomson, ed. Wallace K. Ferguson (Toronto, 1974), no. 61, I27. See Jacques Chomarat, Grammaire et rhetorique chez Érasme (2 vols., Paris, I98I), I, 23I-63. 
that governors had a particular responsibility to speak well and champion scripture. ${ }^{103}$ God's word was the most powerful way to cultivate virtue, peace and the Christian faith. While Erasmus's account of personal piety owed much to the devotio moderna tradition, his emphasis on language as central to the human capacity to understand and embrace Christ and to order moral and political life accordingly was distinctive.

The Huehuetlahtolli drew on Erasmus's argument to elucidate good Nahuatl discourse. Tlahtolli was qualli when it encouraged moral probity and civility. In one speech, a Nahua mother instructed her daughter that if she wished 'to live very well' ( $y$ c nelli huel tinemiz) and be of good reputation, she would follow maternal guidance and the precepts of 'the good song, the good words' (in qualli cuicatl, qualli tlahtolli). The mother confirmed that she, herself, was transmitting these precepts in her advice. She took on the identity of 'a male elder, a female elder, and a pedagogue, a tutor' when she addressed good words to her daughter. ${ }^{104}$ In another discourse, a father instructed his son to imitate ancient usage: 'May you speak [those words] that the ancient man, the ancient woman spoke. ${ }^{\text {I05 }}$ Like humanist Latin, moreover, ancient usage in Nahuatl qualli tlahtolli had a particular grammar, diction and syntax. We overhear a different Nahuatl father tell his son: 'Don't you forget those good letters (qualli tlahtolli), when conversing. If [words] are not spoken correctly by you, then you will practice extensively, then you will correct them according to those [words] that the ancients speak. ${ }^{\text {I06 }}$ Yet ancient usage was also intimately connected to virtuous conduct. As another father exhorted his just-married son, 'Let your words be good (qualli immotlahtol), let them be pure (yectli) because you must respect them, you must honour them. ' ${ }^{\text {'O7 }}$ The creators of the Huehuetlahtolli employed traditional couplet metaphors for wise counsel, 'a lip, a mouth', for repositories of ancient wisdom, 'the black, the red', and for the value of good advice, which was like 'the jade, the turquoise'. ${ }^{108}$ The Tlatelolcans drew on Erasmus's

${ }^{103}$ Erasmus, CWE, LXvI: Handbook of the Christian Soldier, trans. Charles Fantazzi, ed. John O'Malley (Toronto, 1977), 40-7, and CWE, xxvi: The Right Way of Speaking Latin and Greek, trans. Maurice Pope, ed. J. K. Sowards (Toronto, 1985), 369. Cf. Cicero, De Inventione, I.ii, $2-3$.

I04 'in nihuehue, in nilama, in nitlacazcaltiani, in nitlacahuapahuani': Huehuetlahtolli, ed. Bautista, fo. 20v.

I05 'ma tiquihto tlein quihtohua in huehue, in ilama': Huehuetlahtolli, ed. Bautista, fo. 23v.

${ }_{106}$ 'ahmo ticteilcahualtiz in tleyn qualli tlahtolli inic nenonotzalo. Auh intlacamo melahuac quitohua in tehuatl huel timoyeyecoz intla tiquintlahpatiliz in aquique huehueyntin tlahtozque': Huehuetlahtolli, ed. Bautista, fo. $6 \mathrm{v}$.

I07 'ma qualli immotlahtol, auh ma yectli inic xiquimonixtili, inic xiquimonmahuiztili': Huehuetlahtolli, ed. Bautista, fo. 28r.

${ }^{108}$ 'in cententli, in cencamatl': Huehuetlahtolli, ed. Bautista, fos. I5r-v, 22r, 32v, 39r, 4Ir-v, $49 \mathrm{r}, 64 \mathrm{r}$; 'in tilli, in tlapalli', fos. $38 \mathrm{r}$, 39v; 'in chalchihuitl, in teoxihuitl', fos. 8v, 9r, 23v, 27r, 33v, 56v, 6rv among others. See, similarly Florentine Codex, ed. Sahagún, VII, 248. 
defence of the bonae litterae to unpack these metaphors for novices and convent-educated indigenous students. They argued that Nahuatl 'good speech' demonstrated individual virtue, encouraged moral probity in others and tightened the bonds of family.

The Huehuetlahtolli also echoed Erasmus's insistence that rulers should speak well, 'so that [they] are always educating [their people], instructing them' with their words. ${ }^{109}$ In one of the political orations in the collection, a Nahua nobleman reminds a new ruler that the virtue and piety of the city depended on his discourse:

You are [God's] substitute, you are his representative... You serve as [God's] interpreter here, you pronounce his words, you speak for him. The divine word (in ihiyotzin, in tlahtoltzin) of Our Lord does not depart, does not falter, [but rather] it flourishes, it shimmers, it goes honourably, it goes nobly. ${ }^{110}$

A prince's speech, then, needed to be more than qualli. In Book VI of the Florentine Codex, Sahagún had glossed the couplet that the Tlatelolcans used in this passage, 'ihijo, itlatol' or 'ihijotzin, itlatoltzin' in the reverential, as literally 'his breath or spirit[,] or his word'. He emphasised that the metaphor traditionally referred to the speech of rulers (tlatoque, principales) but was now employed by Christian preachers. ${ }^{\text {III }} \mathrm{On}$ their arrival in the Mexico valley, the Franciscans had been struck by 'his breath, his word', a phrase so pleasingly redolent of 2 Timothy 3:I6-I7, 'All scripture is divinely inspired [or breathed] and useful for teaching', and 2 Peter I:2 I, 'Inspired [or breathed into] by the Holy Spirit, the holy men were speaking of God.' They swiftly coopted ihiyotzin, tlahtoltzin to refer to the Christian message. ${ }^{112}$ In this passage of the Huehuetlahtolli, Bautista and the ladinos connected the traditional and missionary meanings of the metaphor - the ruler's speech is also divine speech - to allude to Proverb I6:Io, 'Divination comes from the lips of the king.'

It seems unlikely that the Huehuetlahtolli was openly proposing that tlatoque should be preachers without ordination. Its authors may have been encouraging noble Nahua to consider a path tacitly reopened by

\footnotetext{
109 'ca ye titlacazcaltia, ca ye titlacahuapahua': Huehuetlahtolli, ed. Bautista, fo. 37r. A noble woman receives similar advice, fo. 44r. Cf. Erasmus, Education of a Christian Prince, 99.

${ }_{110}$ in tipatca, in tixiptla, in tixtelolo, in ticamachal...ca ticnahuatlatalhuiya, tictlatenquixtilia, tictlahtolquixtilia. In ahnen yauh, in ahnen huetzi, in xotlatiuh, in pepetzcatiuh, in tleyotiuh, in mahuizzotiuh, in ihiyotzin, in tlahtoltzin Totecuiyo': Huehuetlahtolli, ed. Bautista, fo. 35 r.

III 'su resuello o esp[irit]u o su palabra': Sahagún, Florentine Codex, VII, 246.

${ }^{112}$ For example, Sahagún, Coloquios y doctrina cristiana, ed. León-Portilla, I03-4, II6-17, I46-7, I54-5; Vida y milagros del bien auenturado Sanct Antonio de Padua, ed. Juan Bautista and Agustín de la Fuentes (Mexico: Diego Lopez Davalos, I605), sigs. A4r, C3v. Use of the phrase in context in Bartolomé de Alva, A Guide to Confession Large and Small in the Mexican Language, I634, ed. Barry D. Sell and John Frederick Schwaller, with Lu Ann Homza (Norman, OK, I999), 93, II7, I55, shows a range of possible valences, including 'preaching' or 'holy teaching', 'the Mass' and 'the Gospel'.
} 
the Third Provincial Council ( 1585 ) and the example of noble Texcocan, Antonio del Rincón (I555-I6oI). ${ }^{\mathrm{I} 3}$ Alternatively, they may have been thinking of temporal caciques y gobernadors like themselves. Erasmus had described the prince's religious duties to Charles $\mathrm{V}$ in the dedicatory letter to his Paraphrase on Matthew. Charles had been 'anointed and consecrated expressly' to 'propagate the religion of the gospel'. He was not 'a teacher of the gospel' in the manner of a bishop, but he was 'its champion' (propugnator). ${ }^{\text {II }}$ As Don Antonio Valeriano's letters to Philip II showed, Tlatelolcan caciques considered advocating for indigenous liberal education, Nahuatl preaching and evangelisation as pertaining to their civil office. In fact, another speech in the Huehuetlahtolli depicted the tlatoque of Texcoco, championing Christianity to their people:

You [the people] should pay close attention, you should give yourself completely to Our Lord, God. Perhaps you [singular] have heard it already, you have received it (oticonili, oticcuili), a lip, a mouth, the divine word (in ihiyotzin, in tlahtoltzin). You [plural] should engrave it on your hearts (xocommoyollotican), let it fill you, let it make you drunk (ma amechihuinti ma amechxocomicti) ${ }^{\mathrm{II} 5}$

The rulers' advice was woven from Vulgate places, the threads of which were revealed by the abrupt shift between the second person singular (oticonili, oticcuili) of Job 22:22 'you [singular] shall receive instructions from His mouth' and the second person plural (xocommoyollotican) of Deuteronomy i : 8 'Receive these words of mine in your [plural] hearts and minds. ${ }^{\prime \prime 6}$ The final difrasismo of the passage (ma amechihuinti ma amechxocomicti) evokes, more poetically, Peter's sermon at Pentecost (Acts 2:I-22). Peter explained that the diverse people before him, speaking in tongues, were not 'full with wine' but 'filled with the Holy Spirit'. It had come over them 'like a sudden gust of wind (spiritus)'. The Lord had 'poured from [His] Spirit onto all flesh' and they were drunk with it. Despite their varied natural languages, the crowd before him understood each other perfectly; they spoke to one another in God's word. ${ }^{117}$ Tlatelolcan gramaticos, like Valeriano, were keenly aware of the

${ }^{113}$ Kelly McDonough, 'Indigenous Intellectuals in Early Colonial Mexico: The Case of Antonio del Rincón, Nahua Grammarian and Priest', Colonial Latin American Reviewe, 20 (201 I), I 45-65, I50-I; Stafford Poole, 'Church Law on the Ordination of Indians and Castas in New Spain', Hispanic American Historical Review, 6I (198I), 637-50.

${ }^{114}$ Erasmus, CWE, XLV: Paraphrase on Matthew, trans. Dean Simpson, ed. Robert D. Sider (Toronto, 2008), 5-6, cf. Erasmus, Education of a Christian Prince, 99, 202.

I15 'Xicmocemittili, xicmocenmacatzinco in Totecuiyo, Dios. Azo cententli, cencamatl, oticanili, oticcuili in ihiyotzin, in tlahtoltzin. Xocommoyollotican, ma amechihuinti ma amechxocomicti': Huehuetlahtolli, ed. Bautista, fo. 49r.

${ }_{116}$ 'pone sermones eius in corde tuo': Vulgate, Job 22:22; 'ponite haec verba mea in cordibus et in animus vestris': Vulgate, Deuteronomy iг:18.

${ }_{117}$ 'musto pleni sunt isti', 'repleti sunt omnes Spiritu Sancto', 'tamquam advenientis spiritus vehementis', 'effundam de Spiritu meo super omnem carnem': Vulgate, Acts 2:I3, $2: 4,2: 2,2: 17$. 
challenges that multi-lingual New Spain posed for Christianity. They had observed imperial and papal reversals on language education, vernacular preaching and scripture. ${ }^{\mathrm{II} 8}$ The Huehuetlahtolli made an argument in Nahuatl for the importance of religious education in native tongues and the liberal education of an indigenous elite for evangelisation. When the Mexica were filled by ihiyotzin, tlahtoltzin, they could participate fully in the spiritual discourse of New Spain.

In the Huehuetlahtolli, moreover, divine speech provided a pattern for good human speech in its political, social and familial manifestations. As Erasmus had explained in his Adagia and Paraphrase on Fohn, good speech 'carries the heart of the speaker by an invisible energy into the heart of the hearer'. Thanks to God's first and foremost creation, the word, 'there is no other thing more effective for stirring up every movement of our heart than speech'. ${ }^{119}$ The editors of the Huehuetlahtolli drew on two cultures of 'old words' - traditional Nahua practices of counsel and rhetorical techniques, and the resources of the Vulgate and of Erasmian humanism - to model the affective and instructive power of good vernacular speech in the New World.

The Huehuetlahtolli did not arrest single-handedly the college's decline in the seventeenth century but its argument did not go unheard. We have seen that the Spanish translations of Olmos's speeches circulated widely to defend the capacities of the indios. Fuller engagement with the argument of the Nahuatl orations came in the Enlightenment, when creole patriots and indigenous intellectuals campaigned for the revival of the Colegio de Santa Cruz and the creation of similar institutions. ${ }^{120}$ In particular, the Jesuit Francisco Javier Clavijero ( $1733^{-}-87$ ) responded to Bourbon reforms, secularisation and the deprecations of Mexico by certain Europeans in his Historia Antigua de Mexico (1780). Clavijero included two of the Huehuetlahtolli, the father's speech to his son and the mother's exhortation to her daughter, in his Historia in order 'to confound the arrogance of those who believed that the empire of reason belonged only to Europe'. ${ }^{\text {I2I }}$ While the Jesuit drew on the Spanish versions of the orations, there is every reason to think that he knew the Nahuatl Huehuetahtolli. Clavijero had studied the language extensively, taught in indigenous schools and researched colonial Nahuatl texts in Mexico's convent libraries. He identified Olmos as a collector of antiquities, Bautista as an accomplished

\footnotetext{
${ }^{118}$ Nesvig, 'The Epistemological Politics'.

${ }^{119}$ Erasmus, CWE, XLVI: Paraphrase on Fohn, ed. Jane Phillips (Toronto, I99I), I6.

${ }^{\text {I20 }}$ Mónica Díaz, 'The Education of Natives, Creole Clerics, and the Mexican Enlightenment', Colonial Latin American Review, 24 (2015), 6o-83.

I2I 'a confundir el orgulloso desprecio de los que creen limitado a las regions europeas el imperio de la razón': Francisco Javier Clavijero, Historia Antigua de Mexico, trans. J. Joaquín de Mora, ed. Luis Gonzalez Obregon (2 vols., Mexico, I9I7), I, 335 (quotation), 338-434 (speeches).
} 
writer of evangelical Nahuatl texts and named the Tlatelolcan ladinos as examples of the indigenous facility for higher learning. ${ }^{\text {I22 }}$ Through their good speech in Nahuatl, Clavijero argued, the Mexicans 'engraved their instructions on their children's hearts'. Further, the 'great copiousness of the words that shape the flow of the Mexican language' made it well suited to communicate abstract ethical concepts and Christian doctrine. ${ }^{123}$ Clavijero invoked the Huehuetlahtolli's account of Nahuatl qualli tlahtolli to defend indigenous liberal education and vernacular Christianity in Mexico.

\section{Conclusion}

Contextualising the Huehuetlahtolli in the activities of the Colegio de Santa Cruz sheds light on the significance of old words in the New World. The college's missionaries initiated the collection of Mexican antiquities and the classical framing of the 'speech of the ancients'. Its liberally educated alumni incorporated the speech of the ancient Mesoamerican and Mediterranean worlds in the Huehuetlahtolli. The Tlatelolcans' facility with two rhetorical traditions and two treasuries of 'old words' reveals the rigour of the cultural and linguistic encounter at Santa Cruz. Considerable powers of inventio were necessary to adapt a Nahuatl literary genre using biblical proverbs and humanist rhetorical techniques. To this extent, the literary achievement of the Huehuetlahtolli certainly equals and exceeds the Latin epistles and Nahuatl translations of European texts for which the collegians are often praised.

Both Nahua culture and Erasmian education had encouraged the editors of the Huehuetlahtolli to associate elegant, ancient speech with civil conduct. Language was the tool through which humans could be persuaded towards virtue and in which they could perform their familial and civic duties. While the Florentine Codex collected evidence of Nahuatl qualli tlahtolli, the Huehuetlahtolli used the 'old words' to make an argument in the New World. Contextualising the Nahuatl speeches in Erasmus's theory of speech, which shaped the pedagogy and spiritual culture of Santa Cruz throughout the sixteenth century, helps to reveal its contours. It was critical for evangelisation, the Tlatelolcans posited, that indigenous leaders learned to preach or at least champion the divine word (ihiyotzin, tlahtoltzin), a capacity that depended on their recourse to liberal education. In step with the claims of the friars, the Huehuetlahtolli also posited that for the indios to embrace the divine spirit fully, 'to be drunk with it', they needed to taste it in their native tongue. With the editors' integration

${ }^{\text {I22 }}$ Ibid., I, 4IO 477, II, 359, 39I, 428, 43 O.

${ }^{123}$ 'Tales eran las instrucciones que los mexicanos inculcaban en el ánimo de sus hijos' and 'la excesiva cantidad de estas voces que forman el caudal de la lengua mexicana': Clavijero, Historia, I, 34I, and II, 3I4, respectively. 
of translated Vulgate proverbs, the Huehuetlahtolli showed the potential of Nahuatl scripture. After its printing, the Colegio de Santa Cruz fell on hard times but the collegians' argument for the evangelising capacities and political sophistication of Nahuatl continued to find auditors in the Enlightenment.

Santa Cruz's gramaticos did more than use 'old words' to spread the new word of the Gospels. They demonstrated the capacity of Nahuatl to incorporate the techniques and texts of the bonae litterae. In the context of the renaissance view of languages, this was an important display of the commensurability of Latin and Nahuatl. The Tlatelolcans used their liberal education to show that their vernacular was, indeed, a 'most elegant' form of speech by American and European standards. Like the engraved image of the Mexica in Diego Valadés's Rhetorica Christiana, the Huehuetlahtolli established that the Nahua could wear the classical toga of ancient Rome with aplomb. ${ }^{124}$ There was no reason, the Huehuetlahtolli argued, that the Nahua should 'go about as if they were voiceless' in New Spain. ${ }^{125}$

I24 Valadés, Rhetorica Christiana, I I I.

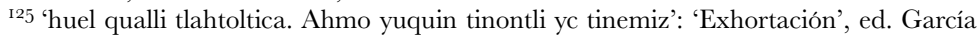
Quintana, I54; Huehuetlahtolli, ed. Bautista, fo. 2v. 